\title{
Systematic Determination of The Ultrastructure of Local Faba Bean (Vicia faba L.) Seeds Using Light and Scanning Electron Microscopes
}

\author{
Nihat Yılmaz ${ }^{1, a, *}$, Handan Şapcı Selamoğlu ${ }^{2, b}$, Zeynep Arı ${ }^{2, c}$, Hatice Bekci ${ }^{2, d}$ \\ ${ }^{1}$ Department of Crop and Animal Production, Safiye Cikrikcioglu Vocational College, Kayseri University, 38280 Kayseri, Turkey \\ ${ }^{2}$ Kayseri University, Yahyall Vocational College, 38280 Kayseri, Turkey
}

*Corresponding author

A R T I C L E I N F O A B S T R A C T

Research Article

The present study was conducted to determine the seed morphologies and macromorphological characteristics of fifteen local faba bean (Vicia faba L.) genotypes collected from different region of Northern Cyprus. The characteristics in the seeds were evaluated using a light microscope (LM) and scanning electron microscope (SEM). SEM pictures were taken of the whole seed and its

Received : 22/12/2020

Accepted : 27/02/2020 details. The scope of the research was examined comparatively using LM and SEM, and the seed shapes, surface ornamentation, and quantitative measurements were determined. Different characteristics for seed size and surface were found among the local faba beans accessions. Seed dimensions were between 12.44 and $24.26 \mathrm{~mm}$ long and between 9.49 and $17.45 \mathrm{~mm}$ wide, colors ranged from yellowish-brown to dark brown, and ornamentation of the seed coat varied. The local faba bean seeds were of subprolate and prolate types. We believe that using this technique to determine the differences among the seeds of different genotypes may play a role in helping to create different programs that can choose specific genotypes to improve cultivars based on the seed

Light microscope Local accession Scanning microscope Seed morphology Vicia faba characteristics.

Vicia faba

\section{Introduction}

Faba beans (Vicia faba L.) belong to the Fabaceae family and are healthy in both human nutrition and for improving the soil as a good rotation plant, as is true of all leguminous plants. The faba bean is a product that can be used in many recipes and can be grown under different ecological conditions. It has high nutritional value and the ability to adapt to large areas, and it is an important rotation crop, especially within cereal-growing regions (Gasim et al., 2004; Torres et al., 2006; Karaköy et al., 2017). Local genotypes, which have been cultivated for centuries, are extremely important because of their high level of adaptation to the conditions within their location. Plant genetic resources consist of village populations characterized by local varieties, their wild relatives, and unused old varieties and lines. Genetic resources are an important and reasonable tool used to contribute the raw material for producing improved cultivars to meet the world's future food and ecological needs (Göl et al., 2016; Yllmaz 2020). It is imperative that genetic resources be conserved to ensure future agricultural production and the future of those who use the product (Sar1 et al., 2016). The faba bean is a valuable vegetable high-protein and energy source that can be consumed both fresh and dry (Duc et al., 2010; Gnanasambandam et al., 2012; Al Barri and Shtaya, 2013; Ammar et al., 2015; Sözen and Karadavut, 2016; De Cillis et al., 2019). Morphological variations are of great importance in the development of a program to breed varieties of the plants. Determining variations in the cultivated species and the distribution of these variations are very important for effective implementation of breeding programs. Variation in the genetics of a quantitative feature is also of great importance for vegetable breeding. A comparison of these variations with each other helps to identify the genetic characteristics of the current population (Balkaya et al., 2010). The morphological characterizations of the varieties in terms of broad bean characteristics have been made by different researches on green bean species, and the morphological 
variations and their distribution have been revealed in detail (Madakbaş et al., 2006; Ekincialp and Şensoy, 2013; Kobal et al., 2019).

Cultivated broad bean varieties are systematically defined under three different groups - V. faba var. equina, $V$. faba var. minor, and $V$. faba var. major. There are great differences among these groups in terms of plant morphology and seed characteristics. Plant height is 40-200 $\mathrm{cm}$, leaf number is $20-70 /$ plant, fodder yield varies between 200 and $480 \mathrm{~kg} / \mathrm{da}$, and raw protein ratios are close to $25 \%$. The plant can grow in warm and rainy climates, where the plant becomes quite high, green mass yield increases, and the dry matter ratio decreases (Manga et al., 1995).

The seed coat consists of five layers, which are, from outside to inside, the epidermis, hypodermis, mechanical layer, parenchyma, and chlorenchyma. The seed contains suberin, lignin, and cutin. The seed surface can be smooth, shiny, jagged, or hairy. They are mostly gray, brown, and black. Special structures on the seeds help them disperse and ensure that the embryo remains dormant (Toker, 2004). The outer surface of the seeds shows differences in ornamental structures, which are used to help classify the plants. In addition, the length and width of the seed and its color and shape are also used in plant classification. The formation of these characteristics are factors that allow the seed to be transported (Mosquero et al., 2002).

Within the scope of this study, the seed morphologies of 15 local faba bean ( $V$. faba L.) genotypes collected from Northern Cyprus were analyzed comparatively using a stereo light microscope (LM) and a scanning electron microscope (SEM). Seed shapes, seed surface ornamentation, and quantitative measurements of the local faba bean genotypes were revealed in detail among the 15 genotypes studied.

\section{Materials and Methods}

The plant material for the present study was composed of local faba bean genotypes grown in different regions (Nicosia, Morphou, Kyrenia, Famagusta, Lefka) of Northern Cyprus. The study samples were collected from 15 local populations grown in Northern Cyprus (Table 1).

LM and SEM were used to determine the seed surfaces. SEM studies were conducted using the Zeiss GeminiSEM 500 (Carl Zeiss AG, Jena, Germany) computer-controlled digital SEM at Erciyes University Technology Research and Application Center, Turkey. Dry seeds of local faba bean genotypes were immersed in a 1:1 solution of chloroform and methanol for $48 \mathrm{~h}$ and dehydrated in a series of ethanol concentrations $(70,90$, and $100 \%)$ to remove surface contaminants. They were then kept in xylene for $72 \mathrm{~h}$, after which the seeds were placed on the sample holder (aluminum stub) with double-sided adhesive tape. Samples were coated with the gold/palladium and then observed by standard techniques using the Zeiss GeminiSEM 500. The macromorphological characteristics of the seeds, such as width, height, color, and shape, were determined using SEM (Mosquero et al., 2002). For each feature, 30-50 measurements were taken, and their averages were calculated.

\section{Results}

LM and SEM results of the macromorphological analyses conducted on the 15 local faba bean genotypes examined for their seed morphology are provided in Table 2. Among the studied genotypes, the seed shape was either prolate or subprolate. The subprolate seeds were from the Bak-05 and Bak-18 genotypes; the shape of the seeds of all the other genotypes were prolate. In addition, when the seeds were examined for surface ornamentation, it was determined that all the seeds had a Pusticulate seed surface. The colors of the different genotypes varied from yellowish-brown to dark brown (Figure 1), and seed surface luster varied from very bright to dull.

In angiosperms, seed morphologies, seed size, color, and seed surface ornamentation are among the important characteristics in taxonomic and evolutionary studies (Juan et al., 1994; Riahi and Zarre, 2009; Kaya et al., 2011; Fagundez and Izco, 2011). In the present study, seed morphological characteristics of 15 local faba bean genotypes cultivated intensively in Northern Cyprus were examined using LM and SEM. SEM was used to evaluate the seed properties and distinguish them for the 15 genotypes (Javadi and Yamaguchi, 2004; Özbek and Ekici, 2014; Kahraman et al., 2014; Mirzaei et al., 2015). The results of the present study showed that the macromorphological structures of the seeds of the 15 genotypes differed from each other (Tables 2), which was an important factor for evaluating the genotypes.

Table 1. Collected faba bean accessions used in the study and their collection location.

\begin{tabular}{l|cc}
\hline Collector & Species & Voucher information and location in Northern Cyprus \\
\hline Y1lmaz et al. & Vicia faba L. & Bak-02: Lefka prov.: Yedidalga village \\
Y1lmaz et al. & Vicia faba L. & Bak-04: Lefka prov.: Yedidalga village \\
Y1lmaz et al. & Vicia faba L. & Bak-05: Morphou prov.: Aydınköy village \\
Y1lmaz et al. & Vicia faba L. & Bak-07: Lefka prov.: Bağliköy village \\
Y1lmaz et al. & Vicia faba L. & Bak-08: Morphou prov.: Bostanc1 village \\
Y1lmaz et al. & Vicia faba L. & Bak-13: Morphou prov.: Doğanc1 village \\
Y1lmaz et al. & Vicia faba L. & Bak-17: Morphou prov.: Zümrütköy village \\
Y1lmaz et al. & Vicia faba L. & Bak-18: Kyrenia prov. Lapta village \\
Y1lmaz et al. & Vicia faba L. & Bak-22: Famagusta prov.: Beyarmudu village \\
Y1lmaz et al. & Vicia faba L. & Bak-23: Famagusta prov.: Vadili village \\
Y1lmaz et al. & Vicia faba L. & Bak-24: Famagusta prov.: Akdoğan village \\
Y1lmaz et al. & Vicia faba L. & Bak-28: Famagusta prov.: Beyarmudu village \\
Y1lmaz et al. & Vicia faba L. & Bak-29: Kyrenia prov.: Lapta village \\
Y1lmaz et al. & Vicia faba L. & Bak-33: Famagusta prov.: Tatlisu village \\
Y1lmaz et al. & Vicia faba L. & Bak-38: Famagusta prov.: Çinarli village \\
\hline
\end{tabular}


Table 2. Seed sizes and morphological characteristics of the Vicia faba L. accessions studied.

\begin{tabular}{c|ccccc}
\hline Accessions & Seed length $(\mathrm{mm})$ & Seed width $(\mathrm{mm})$ & Seed shape & Surface ornamentation & Seed L/W \\
\hline Bak-02 & 19.76 & 13.46 & Prolate & Pusticulate & 1.47 \\
Bak-04 & 20.01 & 14.49 & Prolate & Pusticulate & 1.38 \\
Bak-05 & 12.44 & 9.49 & Subprolate & Pusticulate & 1.31 \\
Bak-07 & 18.35 & 13.44 & Prolate & Pusticulate & 1.37 \\
Bak-08 & 21.68 & 15.77 & Prolate & Pusticulate & 1.38 \\
Bak-13 & 24.26 & 16.03 & Prolate & Pusticulate & 1.51 \\
Bak-17 & 24.19 & 17.45 & Prolate & Pusticulate & 1.39 \\
Bak-18 & 19.47 & 14.82 & Subprolate & Pusticulate & 1.32 \\
Bak-22 & 20.89 & 15.28 & Prolate & Pusticulate & 1.37 \\
Bak-23 & 22.20 & 15.55 & Prolate & Pusticulate & 1.43 \\
Bak-24 & 21.14 & 14.95 & Prolate & Pusticulate & 1.41 \\
Bak-28 & 22.56 & 15.70 & Prolate & Pusticulate & 1.44 \\
Bak-29 & 17.17 & 12.12 & Prolate & Pusticulate & 1.42 \\
Bak-33 & 19.41 & 13.91 & Prolate & Pusticulate & 1.40 \\
Bak-38 & 20.99 & 14.94 & Prolate & Pusticulate & 1.40 \\
\hline
\end{tabular}
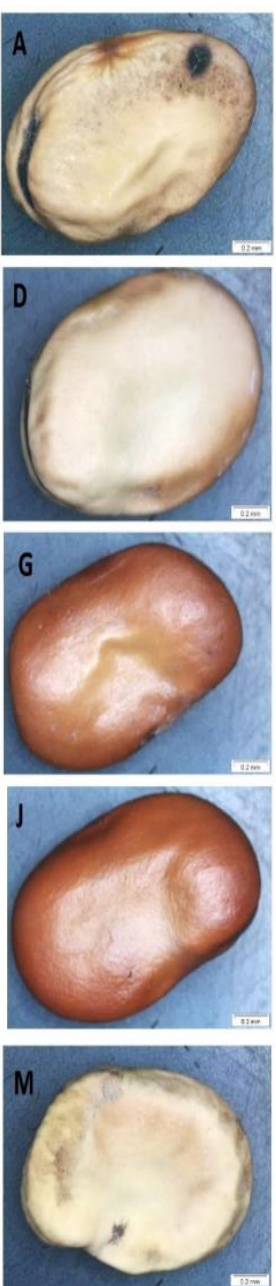

Figure 1. Stereo light microscope photographs of faba bean genotypes. A) Bak-02, B) Bak-4, C) Bak-5, D) Bak7, E) Bak-8, F) Bak-13, G) Bak-17, H) Bak-18, I) Bak-22, Bak-8, F) Bak-13, G) Bak-17, H) Bak-18, I) Bak-22, J) BakJ) Bak-23, K) Bak-24, L) Bak-28, M) Bak-29, N) Bak-33, 23, K) Bak-24, L) Bak-28, M) Bak-29, N) Bak-33, and O) and O) Bak-38.

One study on the seed morphology of faba beans has included the ultrasculpture of pollen grains and the surface and macro- and microstructures of the seeds of broad beans, peas, and common beans (Kurkina et al., 2020).
Bak-38.

In a study carried out by Kurkina et al. (2020) has stressed that seed characteristics are determined by ecological factors that have an important effect on the diversity of pod seed genotypes and that the growth and genotypes of plants may differ in their development because 
of this diversity. In addition, the results of their study suggest that it is predicted that these seed differences belonging to different genotypes can be used in breeding studies and will make important contributions to the programs that breed these plants for specific morphological features.

We determined that there is a homogeneity among the genotypes in terms of seed length and width. Accordingly, Bak-17 had the largest seed size, while Bak-05 had the smallest. In general, the shape of the seeds in all but two genotypes were prolate, the seeds from the remaining two were subprolate. Seed surface ornamentation was also examined. The results showed that the seed surface of the local faba bean genotypes has pusticulate ornamentation (Figure 2 and Table 2).

\section{Conclusions}

The present study provides the first detailed information on the morphological traits of the seeds of local faba beans grown in Northern Cyprus. It has been determined that the seed characteristics of the studied genotypes were mostly prolate shape and differ from each other. These characteristics can be easily determined using SEM. Consequently, results based on LM and SEM analyses, have shown that seed sizes and surface patterns have important morphological features that distinguish the studied genotypes from each other. Therefore, the fact that there was no previous systematic determination of the macro and micro-morphology of local seeds study in Northern Cyprus has increased the importance of this study and it was considered that seed morphological characterization studies alone are insufficient. It is believed that additional studies using LM and SEM for morphological characterizations and analyses may help to support information that distinguishes genotypes in breeding studies.

\section{Conflict of Interest}

The authors declare that there is no conflict of interest.

\section{Acknowledgements}

This study is financially supported by The Scientific and Technological Research Council of Turkey (TUBITAK), Project number: 110-O-117. The authors thank to TUBITAK for the financial support. This study was supported by Scientific Research Commission of Kayseri University (Project No: FHD-2020-1004.).

\section{References}

Al Barri T, Shtaya MJY. 2013. Phenotypic characterization of faba bean (Vicia faba L.) landraces grown in Palestine. Journal of Agriculture Science, 5(2): 110-117. doi: https:// doi.org/10.5539/jas.v5n2p110

Ammar MH, Alghamdi SS, Migdadi HM, Khan MA, Ehab HEH, Sulieman AA. 2015. Assessment of genetic diversity among faba bean genotypes using agro-morphological and molecular markers. Saudi Journal of Biological Sciences 22: 340-350. doi: https://doi.org/10.1016/j.sjbs.2015.02.005

Balkaya A, Özbakır M, Karaağaç O. 2010. Evaluation of variation and fruit characterization of pumpkin (Cucurbita moschata duch.) populations collected from black sea region. The Journal of Agricultural Science, 16(1): 17-25.
De Cillis F, Leoni B, Massaro M, Renna M, Santamaria P. 2019. Yield and quality of faba bean (Vicia faba L. var. major) genotypes as a vegetable for fresh consumption: a comparison between Italian landraces and commercial varieties. Agriculture. 9: 253. https://doi.org/10.3390/agriculture9120 253.

Duc G, Bao S, Baum M, Redden R, Sadiki M, Suso MJ, Vishniakova M, Zong X. 2010 Diversity maintenance and use of Vicia faba L. genetic resources. Field Crops Research, 115: 270-278.

Ekincialp A, Şensoy S. 2013. Determination of some vegetable features of Van lake basin bean genotypes. YYU, Journal of Agricultural Sciences, 23(2): 102-111. (in Turkish)

Fagundez J, Izco J. 2011. Seed morphology and anatomy of the Mediterranean pentamerous species of Erica (Ericaceae). Turkish Journal of Botany, 35: 643-651.

Gasim S, Abel S, Link W. 2004. Extent, variation and breeding impact of natural cross-fertilization in German winter faba beans using hilum colour as marker. Euphytica, 136: 193200.

Gnanasambandam A, Paull J, Torres A, Kaur S, Leonforte T, Li H, Zong X, Yang T, Materne M. 2012. Impact of molecular technologies on faba bean (Vicia faba L.) breeding strategies. Agronomy, 2: 132-166, doi:https://doi.org/10.3390/ agronomy2030132

Göl Ş, Doğanlar S, Frary A. 2016. Genetic diversity and population structure of faba bean (Vicia faba) from Turkey. HortScience, 51(8): 980-983. doi: https://doi.org/10.21273/ HORTSCI11022-16

Javadi F, Yamaguchi H. 2004. A note on seed coat and plumule morphological variation in the genus Cicer (Fabaceae). Biology, 56: 7-16.

Juan R, Pastor J, Fernandez I. 1994. Seed morphology in Veronica L. (Scrophulariaceae) from south-west Sapin. Botanical Journal of the Linnean Society, 115: 133-143.

Kahraman A, Chidire H, Dogan M. 2014. Anatomy, macro- and micromorphology of Lathyrus sect. Nissolia (Fabaceae) and their taxonomic significance. Proceedings of the National Academy of Sciences, 84: 407-417.

Karaköy T, Demirbaş A, Toklu F, Özkan H, Karagöl ET, Uncuer D, Gürsoy N. 2017. Agronomic and morphological characterization of faba bean landraces (Vicia faba 1.) collected from different region of Turkey. KSU Journal of Natural. Science, 20 (Special issue): 356-361. doi: https://doi.org/10.18016/ksudobil.349299.

Kaya A, Ünal M, Özgökçe F, Doğan B, Martin E. 2011. Fruit and seed morphology of six species previously placed in Malcolmia (Brassicaceae) in Turkey and their taxonomic value. Turkish Journal of Botany, 35: 653-662.

Kobal Bekar N, Sağlam N, Balkaya A. 2019. The Evaluation of Variation in terms of Broad Bean Characteristics and Broad Bean Quality of Some Bean Genotypes. Yuzuncu Yil Univ. Journal of Agriculture Science, 29: 127-135.

Kurkina YN, Kieu NTZ, Kolesnikov DA, Maradudina ON, Lazarev AV. 2020. Analysis of the ultrastructure of pollen grains and seeds to identify plant materials. EurAsian Journal of BioSciences 14: 1489-1494.

Madakbaş SY, Özçelik H, Ergin M. 2006. Determination of the differences between the lines determined from the dwarf green bean populations in the Çarşamba Plain. Harran Univ. Journal of Agriculture Faculty, 10: 71-77.

Manga İ, Acar Z, Ayan İ. 1995. Legume forage crops. OMU Tech., 274: 65 .

Mirzaei L, Assadi M, Nejadsatar T, Mehregan I. 2015. Comparative seed and leaf micromorphology of Colutea species (Fabaceae) from Iran. Environmental and Experimental Biology. 13: 183-187.

Mosquero MAM, Juan R, Pastor JE. 2002. Morphological and anatomical studies on nutlets of Nepeta L. (Lamiaceae) from South-West Spain. Acta Botanica Malacitana, 27: 15-26. 
Özbek F, Ekici M. 2014. Morphological, anatomical, pollen and seed morphological properties of Melilotus bicolor Boiss. \& Balansa (Fabaceae) endemic to Turkey. Australian Journal of Crop Science, 8: 543-549.

Riahi M, Zarre S. 2009. Seed development in Astragalus cemerinus and A. ruscifolius (Fabaceae), and its systematic implications. Acta Biologica Cracoviensia Series Botanica, 51: 111-117.

Sarı N, Solmaz İ, Pamuk S, Çetin MB. 2016. Seed and pod characteristics of different seed coat color beans collected from Black Sea Region. Academia Journal of Agricultural Research, 5: 21-28. (in Turkish).
Sözen Ö, Karadavut U. 2016. Determination of morphological and phenological properties of faba beans grown in Eastern Mediterranean Region of Turkey. Journal of Field Crops Central Research Institute, 25: 209-217. doi: https://doi.org/10.21566/tarbitderg.281344

Toker MC. 2004. Plant Morphology. Ank. Univ. Faculty of Science. (second edition in Turkish), 56p.

Torres AM, Roman B, Avila CM, Satovic Z, Rubiales D, Sillero JC, Cubero JI, Moreno MT. 2006. Faba bean breeding for resistance against biotic stresses: towards application of marker technology. Euphytica. 147: 67-80.

Y1lmaz N. 2020. Morphological and molecular characterization of local faba bean (Vicia faba 1.) accessions using inter-simple sequence repeat (ISSR) markers. Fresenius Environmental Bulletin 29: 3756-3763. 